\title{
Clinical Reasoning: A misdiagnosis of atypical trigeminal neuralgia
}

Jaclyn R. Duvall, MD, and Carrie E. Robertson, MD

Correspondence

Neurology ${ }^{\circledR}$ 2019;93:124-131. doi:10.1212/WNL.0000000000007790

Dr. Robertson

Robertson.Carrie@mayo.edu

\section{Section 1}

A 47-year-old man presented with right-sided facial pain that started 2 years prior. He described the pain as extremely intense, stabbing along the right jaw, lasting 5-60 seconds. This pain was exacerbated by chewing, and to a lesser degree, by brushing his teeth. The pain was so intense that he avoided eating when possible, leading to a 20-pound weight loss. When he did eat, he would try to chew on the left side of his mouth. Around the onset of these symptoms, he also noticed a persistent numbness and burning extending from the right lower earlobe to the lateral angle of the jaw that was exacerbated by turning his head to the right.

The patient was given a diagnosis of atypical trigeminal neuralgia (TN) and sent to our headache clinic for further management.

\section{Questions for consideration:}

1. What features are typical and atypical for classical TN?

2. What is your differential diagnosis in this patient presenting with facial pain?

GO TO SECTION 2 


\section{Section 2}

$\mathrm{TN}$ is characterized by "recurrent paroxysms of unilateral pain in the distribution(s) of one or more divisions of the trigeminal nerve," ${ }^{1}$ most often the maxillary and mandibular divisions. As outlined by the International Classification of Headache Disorders, 3rd edition, TN pain ${ }^{1}$ :

A. Does not radiate beyond the trigeminal distribution B. Lasts from a fraction of a second to 2 minutes (recurrent paroxysms may occur in clusters lasting longer)

C. Is severe in intensity and electric shock-like, shooting, stabbing, or sharp in quality

D. Is precipitated by innocuous stimuli within the trigeminal nerve distribution

Patients tend to be asymptomatic between paroxysms, though a subset of patients may develop a prolonged continual background pain, with fluctuations in intensity and periods of remission and recurrence that parallel the paroxysmal pain. ${ }^{2}$ Approximately $99 \%$ of patients with TN report at least some of their attacks being associated with a trigger. ${ }^{2-4}$ In one large study, the most commonly described triggers were gentle touching of the face $(83 \%$ of patients) and talking (59\%), followed by chewing (41\%) and tooth brushing (36\%). When cutaneous triggers are present, the most common trigger zones are around the mouth and nose, though anywhere on the face may be described. ${ }^{3,5}$ Some patients may notice a transient refractory period following a paroxysmal pain, where additional pain cannot be triggered. ${ }^{1}$ In contrast to the classic paroxysmal, shooting, stabbing, or shock-like qualities used to describe neuralgic pain, neuropathic pain tends to involve more persistent burning, tingling, or numbness. If the patient has features of neuropathy (numbness), persistent pain, bilateral pain, isolated supraorbital involvement, or a lack of sensory triggers, an alternative diagnosis should be considered. This could include dental pathology, parotid pathology, or an alternative neuralgia/neuropathy. See the table for a comprehensive overview of conditions that may mimic TN.

Our patient described paroxysmal severe shooting facial pain, lasting seconds at a time. He reported innocuous triggers, including chewing and possibly brushing his teeth. Interestingly, however, he denied all other classical TN triggers, including cutaneous triggers. He also described an atypical persistent pain that was more neuropathic (numbness/ burning) than neuralgic, and this extended over the angle of the jaw and into the pinna of the ear, both territories that are outside of the distribution of the trigeminal nerve. Given the atypical presentation, we were concerned about an alternative diagnosis.

\section{Questions for consideration:}

1. What additional historical details should be asked to narrow the differential?

2. What additional examination tests might be helpful? 
Table Conditions that may mimic trigeminal neuralgia

\begin{tabular}{|c|c|c|c|c|}
\hline Condition & $\begin{array}{l}\text { Most common } \\
\text { location }\end{array}$ & $\begin{array}{l}\text { Pain } \\
\text { characteristics }\end{array}$ & Aggravating factors & Things you should know or look for \\
\hline \multicolumn{5}{|l|}{ Dental } \\
\hline Caries & Affected tooth & $\begin{array}{l}\text { Intermittent to } \\
\text { continuous dull }\end{array}$ & $\begin{array}{l}\text { Sweet foods, hot or cold } \\
\text { stimuli }\end{array}$ & Visible decay \\
\hline Cracked tooth & Affected tooth & $\begin{array}{l}\text { Intermittent } \\
\text { dull or sharp }\end{array}$ & $\begin{array}{l}\text { Biting/chewing, hot or cold } \\
\text { stimuli }\end{array}$ & Often difficult to visualize crack \\
\hline Dry socket & Affected tooth & $\begin{array}{l}\text { Continuous, } \\
\text { deep, sharp }\end{array}$ & Hot or cold stimuli & Loss of clot, exposed bone \\
\hline TMJ dysfunction (TMJ disease) & $\begin{array}{l}\text { Jaw and surrounding } \\
\text { muscles, radiation to } \\
\text { ear and temple }\end{array}$ & $\begin{array}{l}\text { Constant or } \\
\text { intermittent, } \\
\text { tender, aching }\end{array}$ & $\begin{array}{l}\text { Forced mouth opening, jaw } \\
\text { manipulation, chewing }\end{array}$ & $\begin{array}{l}\text { May be complication of arthritis, jaw } \\
\text { locking or popping }\end{array}$ \\
\hline Sinusitis & $\begin{array}{l}\text { Nasal passages, } \\
\text { above the eyes, } \\
\text { cheeks }\end{array}$ & $\begin{array}{l}\text { Pressure, } \\
\text { tenderness, } \\
\text { aching }\end{array}$ & Bending over & $\begin{array}{l}\text { Fever, swelling, purulent nasal } \\
\text { discharge, reduced sense of smell and } \\
\text { taste, positive CT or endoscopy }\end{array}$ \\
\hline \multicolumn{5}{|l|}{ Parotid } \\
\hline Sialadenitis & $\begin{array}{l}\text { Submandibular or } \\
\text { parotid region }\end{array}$ & $\begin{array}{l}\text { Gradual, } \\
\text { constant }\end{array}$ & Tender to palpation & $\begin{array}{l}\text { Swelling, erythema over the gland, } \\
\text { fever, chills }\end{array}$ \\
\hline Salivary stone & $\begin{array}{l}\text { Submandibular or } \\
\text { parotid region }\end{array}$ & $\begin{array}{l}\text { Intermittent, } \\
\text { dull }\end{array}$ & $\begin{array}{l}\text { Salivation (eating or smelling } \\
\text { foods) }\end{array}$ & $\begin{array}{l}\text { Tenderness at gland, palpable stone, } \\
\text { lack of salivary flow }\end{array}$ \\
\hline FBS & $\begin{array}{l}\text { Submandibular or } \\
\text { parotid region }\end{array}$ & $\begin{array}{l}\text { Paroxysmal } \\
\text { severe, sharp }\end{array}$ & $\begin{array}{l}\text { Salivation (eating or smelling } \\
\text { foods) }\end{array}$ & $\begin{array}{l}\text { No sensory triggers, history of prior } \\
\text { head/neck surgery, improves after } \\
\text { a few bites }\end{array}$ \\
\hline \multicolumn{5}{|l|}{ Neoplasm } \\
\hline Benign/malignant & $\begin{array}{l}\text { Submandibular or } \\
\text { parotid region }\end{array}$ & $\begin{array}{l}\text { Persistent dull } \\
\text { pain }\end{array}$ & $\begin{array}{l}\text { Swallowing, opening mouth } \\
\text { widely }\end{array}$ & $\begin{array}{l}\text { Lump or swelling, facial numbness, } \\
\text { muscle weakness if masseter involved }\end{array}$ \\
\hline Giant cell arteritis & $\begin{array}{l}\text { Temporal region or } \\
\text { holocephalic }\end{array}$ & $\begin{array}{l}\text { Typically } \\
\text { continuous dull } \\
\text { pain (new or } \\
\text { worsening) }\end{array}$ & Scalp or vessel tenderness & $\begin{array}{l}\text { Visual disturbance, jaw claudication, } \\
\text { fevers/chills, night sweats, weight loss, } \\
\uparrow E S R / C R P \text {, temporal artery biopsy }\end{array}$ \\
\hline Carotid & & & & $\begin{array}{l}\text { Evaluation for Horner for all carotid } \\
\text { pathology (ptosis/miosis/anhidrosis) }\end{array}$ \\
\hline Dissection & $\begin{array}{l}\text { Neck, lower face/jaw, } \\
\text { retro-orbital }\end{array}$ & $\begin{array}{l}\text { Thunderclap or } \\
\text { acute tearing } \\
\text { pain or } \\
\text { progressive or } \\
\text { throbbing }\end{array}$ & Head/neck movement & $\begin{array}{l}\text { May have preceding trauma to neck or } \\
\text { whiplash injury }\end{array}$ \\
\hline Carotidynia & $\begin{array}{l}\text { Tender carotid } \\
\text { bifurcation, may } \\
\text { radiate to ipsilateral } \\
\text { face or ear }\end{array}$ & $\begin{array}{l}\text { Variable } \\
\text { temporal } \\
\text { patterns, } \\
\text { aching/ } \\
\text { tenderness, } \\
\text { sore throat }\end{array}$ & $\begin{array}{l}\text { Pressure over carotid artery; } \\
\text { coughing, swallowing, } \\
\text { Valsalva, cold weather, head } \\
\text { movement }\end{array}$ & $\begin{array}{l}\text { Controversial-Imaging may reveal } \\
\text { focal eccentric thickening of the } \\
\text { carotid wall leading to luminal } \\
\text { narrowing, but is otherwise normal }\end{array}$ \\
\hline
\end{tabular}

\section{Primary headache disorders}

\begin{tabular}{|c|c|c|c|c|}
\hline Migraine & $\begin{array}{l}\text { Hemicranial > } \\
\text { holocephalic }\end{array}$ & $\begin{array}{l}\text { Pulsating or } \\
\text { throbbing, } \\
\text { lasting } 4 \text { hours } \\
\text { or more }\end{array}$ & $\begin{array}{l}\text { Physical activity, lights, sounds, } \\
\text { certain foods, hormonal } \\
\text { changes }\end{array}$ & $\begin{array}{l}\text { Nausea, sensory phobias (light/ } \\
\text { sound), stereotypical attacks, family } \\
\text { history }\end{array}$ \\
\hline SUNCT & $\begin{array}{l}\text { Orbital, supraorbital, } \\
\text { or temporal }\end{array}$ & $\begin{array}{l}\text { Severe, } \\
\text { stabbing, } \\
\text { lasting a few } \\
\text { seconds to } \\
\text { a couple of } \\
\text { minutes }\end{array}$ & $\begin{array}{l}\text { Usually spontaneous; can } \\
\text { have sensory triggers include } \\
\text { touching face/scalp, chewing, } \\
\text { talking, coughing, blowing } \\
\text { nose, light }\end{array}$ & $\begin{array}{l}\text { Autonomic features (conjunctival } \\
\text { injection, tearing, rhinorrhea, facial } \\
\text { flushing/sweating, ptosis/miosis) }\end{array}$ \\
\hline
\end{tabular}


Table Conditions that may mimic trigeminal neuralgia (continued)

\begin{tabular}{|c|c|c|c|c|}
\hline Condition & $\begin{array}{l}\text { Most common } \\
\text { location }\end{array}$ & $\begin{array}{l}\text { Pain } \\
\text { characteristics }\end{array}$ & Aggravating factors & Things you should know or look for \\
\hline TNO & $\begin{array}{l}\text { Unilateral distribution } \\
\text { of trigeminal nerve, } \\
\text { V2/V3 most common }\end{array}$ & $\begin{array}{l}\text { Numbness, } \\
\text { burning, } \\
\text { continuous, } \\
\text { paresthesia or } \\
\text { dysesthesias }\end{array}$ & Light touch & $\begin{array}{l}\text { Further diagnostic evaluation } \\
\text { indicated especially if progressive as } \\
\text { this may be the first manifestation of } \\
\text { tumor or relapse of prior neoplastic } \\
\text { process, trauma is most common } \\
\text { mechanism leading to TNO (often } \\
\text { iatrogenic) }\end{array}$ \\
\hline
\end{tabular}

\section{Idiopathic}

\section{Neoplastic}

Inflammatory/autoimmune

\section{Traumatic}

Blunt, dental

\begin{tabular}{|c|c|c|c|c|}
\hline \multicolumn{5}{|l|}{ Anesthesia dolorosa } \\
\hline $\begin{array}{l}\text { Numb chin syndrome } \\
\text { ("mental neuropathy") }\end{array}$ & $\begin{array}{l}\text { Unilateral lower lip } \\
\text { and chin }\end{array}$ & Numbness & Light touch, biting lip & $\begin{array}{l}\text { Red flag association with breast, lung, } \\
\text { and lymphoproliferative malignancies, } \\
\text { although dental procedures are most } \\
\text { common culprit }\end{array}$ \\
\hline Postherpetic neuralgia & $\begin{array}{l}\text { Dermatome of single } \\
\text { nerve or nerve root }\end{array}$ & $\begin{array}{l}\text { Continuous or } \\
\text { intermittent, } \\
\text { electrical, } \\
\text { burning, sharp }\end{array}$ & $\begin{array}{l}\text { Light touch in affected } \\
\text { dermatome }\end{array}$ & $\begin{array}{l}\text { Vesicles or scarring from herpetic } \\
\text { rash; despite its name, postherpetic } \\
\text { neuralgia is actually a neuropathy or } \\
\text { neuronopathy }\end{array}$ \\
\hline Burning mouth syndrome & Mouth, gums, lips & $\begin{array}{l}\text { Burning, } \\
\text { continuous }\end{array}$ & No clear factors & $\begin{array}{l}\text { May be seen with xerostomia, } \\
\text { candidiasis, GERD, poor oral hygiene }\end{array}$ \\
\hline \multicolumn{5}{|l|}{ Other neuralgias } \\
\hline $\begin{array}{l}\text { Glossopharyngeal neuralgia } \\
\text { (CN IX) }\end{array}$ & $\begin{array}{l}\text { Ear, base of tongue, } \\
\text { tonsillar fossa, angle } \\
\text { of the jaw }\end{array}$ & $\begin{array}{l}\text { Paroxysmal } \\
\text { severe, } \\
\text { electrical, } \\
\text { shooting, } \\
\text { stabbing, sharp }\end{array}$ & $\begin{array}{l}\text { Swallowing, yawning, } \\
\text { coughing, touching the ear }\end{array}$ & $\begin{array}{l}10 \% \text { of cases associated with syncope/ } \\
\text { arrhythmia, consider Holter monitor }\end{array}$ \\
\hline $\begin{array}{l}\text { Nervus intermedius } \\
\text { neuralgia ("geniculate } \\
\text { neuralgia") (CN VII) }\end{array}$ & $\begin{array}{l}\text { Deep inside and } \\
\text { behind ear }>\text { face/jaw }\end{array}$ & $\begin{array}{l}\text { Paroxysmal } \\
\text { severe, } \\
\text { electrical, } \\
\text { shooting, } \\
\text { stabbing, sharp }\end{array}$ & $\begin{array}{l}\text { Touch over or within the ear } \\
\text { canal (cotton swabs) }\end{array}$ & $\begin{array}{l}\text { May occur with Bell palsy; disorders of } \\
\text { lacrimation, salivation, and taste may } \\
\text { occur }\end{array}$ \\
\hline \multicolumn{5}{|l|}{$\begin{array}{l}\text { Cervical cutaneous } \\
\text { neuralgias }\end{array}$} \\
\hline $\begin{array}{l}\text { Great auricular neuralgia } \\
\text { (branch of C2 and C3) }\end{array}$ & $\begin{array}{l}\text { Anterior } \\
\text { (preauricular, parotid, } \\
\text { jaw angle); posterior } \\
\text { (mastoid and } \\
\text { posteroinferior } \\
\text { pinna) }\end{array}$ & $\begin{array}{l}\text { Paroxysmal } \\
\text { severe, } \\
\text { electrical, } \\
\text { shooting, } \\
\text { stabbing, sharp }\end{array}$ & $\begin{array}{l}\text { Turning head/neck position } \\
\text { during sleep, exertion, lifting } \\
\text { ipsilateral arm }\end{array}$ & $\begin{array}{l}\text { Neuralgia of the great auricular and } \\
\text { lesser occipital nerves differ from } \\
\text { neuropathy (no numbness); look for } \\
\text { mass or irritation near nerve course }\end{array}$ \\
\hline $\begin{array}{l}\text { Lesser occipital neuralgia } \\
\text { (branch of C2 and C } 3 \text { ) }\end{array}$ & $\begin{array}{l}\text { Posterior scalp, } \\
\text { superior pinna, } \\
\text { supra-auricular scalp }\end{array}$ & $\begin{array}{l}\text { Paroxysmal } \\
\text { severe, } \\
\text { electrical, } \\
\text { shooting, } \\
\text { stabbing, sharp }\end{array}$ & $\begin{array}{l}\text { Movement, tenderness over } \\
\text { posterior skull base }\end{array}$ & \\
\hline
\end{tabular}

Abbreviations: CRP = C-reactive protein; ESR = erythrocyte sedimentation rate; FBS = first bite syndrome; GERD = gastroesophageal reflux disease; SUNCT = short-lasting unilateral neuralgiform headache with conjunctival injection and tearing; TMJ = temporomandibular joint; TNO = trigeminal neuropathy.

GO TO SECTION 3 


\section{Section 3}

A careful history is essential in the diagnosis of lower facial pain and should include the following:

- Head/neck surgery or trauma

- Cancer and systemic symptoms (fever/chills, night sweats, weight loss)

- Dental disease/procedures

- Symptoms suggestive of sympathetic pathway injury (ptosis or miosis)

- Clicking or popping of the jaw

- Rash (vesicles)

- All aggravating/relieving factors: swallowing, yawning, chewing, movement of temporomandibular joint, light touch, cool breeze or cold, head/neck positions, straining, talking, brushing teeth

On further questioning, our patient recalled a surgery just prior to the onset of pain, involving resection of a parapharyngeal pleomorphic adenoma for which he underwent resection via a right cervico-parotid approach. Follow-up MRI and magnetic resonance angiography revealed no tumor recurrence or other pathology to explain his neuropathic symptoms. On an extensive review of his triggers, he explained that while chewing on the right side did consistently trigger severe pain, if he could "push through," the pain would subside after a minute, raising the question of a TN refractory period. Most interestingly, however, he also revealed that just thinking about food or smelling food could trigger similar severe pain. With regard to the constant burning pain over the angle of the jaw and ear, this was milder and did not fluctuate with his paroxysmal pains.

On examination, our patient had reduced pin sensation over the right lower ear extending along the angle of the jaw. Given the unusual triggering of pain with food smells, we performed a bedside provocation of salivation by giving the patient a sour candy. Even before putting the candy in his mouth, the patient began to experience his typical paroxysmal stabbing pain. This became severe when he put the candy in his mouth, prior to any chewing. After chewing for about 5 seconds, the excruciating pain settled back down to his constant numbness and burning. The remainder of his neurologic examination was normal.

\section{Questions for consideration:}

1. What is the likely diagnosis for this patient's stabbing pain?

2. What additional diagnosis might he have? 


\section{Section 4}

Our patient likely had 2 different diagnoses. The stabbing pain brought on by salivation and relieved after chewing for a few bites was consistent with a diagnosis of first bite syndrome (FBS). FBS is a known potential complication of surgeries in the parapharyngeal or upper cervical region, especially when there is damage to the sympathetic chain. ${ }^{6,7}$ FBS can also occur with other injury to the sympathetic chain, including cervical arterial dissection or tumor invasion. The pain is typically described as a severe cramping or electric shock-like pain occurring in the region of the parotid gland and mandibular angle that occurs with the first bite of each meal and diminishes over the next several bites. ${ }^{8}$ Acidic or sour food may be particularly strong triggers for pain. ${ }^{6}$ Given the prominent trigger with salivation, it may be helpful to perform a bedside provocation of salivation, as we did in this case. Other than this bedside test, the neurologic examination in isolated FBS is often normal unless there has been damage to the sympathetic pathway. In this case, there may be an associated Horner syndrome, occurring in about $70 \%$ of patients. ${ }^{6}$

In the absence of ipsilateral upper neck or facial surgery, diagnostic imaging should be completed to exclude cancer of the deep lobe of the parotid gland, submandibular gland, or parapharyngeal space. Initial negative imaging should be repeated, given reports of tumor becoming visible several months after the onset of pain. ${ }^{9}$

The pathophysiology of this syndrome is believed to involve sympathetic and parasympathetic dysregulation. ${ }^{8,10}$
Sympathetic secretomotor innervation of the parotid produces a small amount of thick saliva that inhibits secretion, whereas parasympathetic secretomotor input produces a large volume of watery saliva that stimulates secretion. ${ }^{10}$ Loss of sympathetic innervation to the parotid gland leads to denervation of sympathetic receptors located on parotid myoepithelial cells, which also contain parasympathetic receptors. ${ }^{8}$ These receptors are hypothesized to become hypersensitive to parasympathetic stimulation, resulting in a very intense contraction of these myoepithelial cells at the first bite. ${ }^{8}$

Our patient's case was complicated by a concurrent diagnosis of great auricular neuropathy presenting as constant numbness and burning along the lower earlobe to the lateral angle of the jaw. The great auricular nerve is a peripheral branch of the superficial cervical plexus that wraps around the sternocleidomastoid, before dividing into 2 branches that provide sensory innervation to the lower ear and the angle of the jaw, often extending the length of the mandible to the lateral chin (figure). Its superficial location makes it vulnerable to traumatic and iatrogenic injury, especially following rhytidectomy (facelift), carotid endarterectomy, and other cervical surgeries.

\section{Discussion}

Our case demonstrates a classic presentation of FBS initially misdiagnosed as atypical TN. Facial pain isolated to the V3 distribution can pose a diagnostic challenge for even the most experienced neurologist. While well-recognized among head

Figure Sympathetic and parasympathetic innervation of the parotid gland

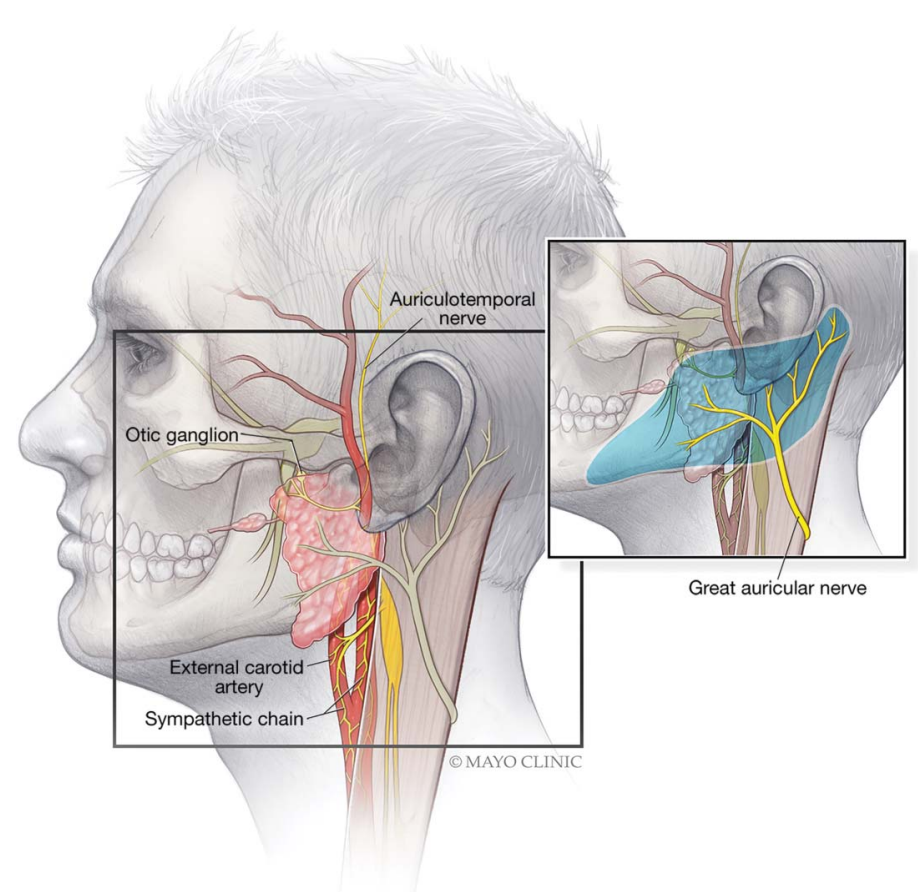

The sympathetics are supplied by the sympathetic chain coming off of the superior cervical ganglion. The parasympathetic innervation comes off of a branch of the auriculotemporal nerve. The inset on the right shows the great auricular nerve wrapping around the sternocleidomastoid to provide sensory innervation over the lower ear and angle of the jaw. Our patient, like many patients undergoing surgery to the deep parotid region, had injury to both the sympathetics as well as great auricular nerve resulting in first bite syndrome with concurrent lower face numbness. Image used with permission of Mayo Foundation for Medical Education and Research. All rights reserved. 




and neck surgeons as a potential surgical complication, FBS is not often considered by neurologists during the evaluation of lower facial pain. Similar to our patient, these surgeries can also be complicated by cutaneous neuropathies (especially great auricular or auriculotemporal nerves) or iatrogenic Horner syndrome, highlighting the potential diagnostic challenge in these cases.

Although the pain of FBS may resolve spontaneously, associated pain with this syndrome can be significantly disabling, leading to avoidance of food completely and in some cases, significant weight loss and malnutrition. No consensus exists for the best treatment strategy. ${ }^{9}$ Early parotidectomy in the context of malignant parotid tumors has consistently relieved pain. ${ }^{8}$ Anticonvulsants, alone or in combination with tricyclic antidepressants, may decrease the severity or duration of the pain. ${ }^{9}$ Recently, botulinum toxin injections into the parotid gland have been employed with success, although a standard method of injection is not established and the duration of pain relief is variable. ${ }^{9,10}$

FBS, although rare, should be considered in the differential of V3 distribution facial pain and its heightened awareness may enhance the neurologist's ability to accurately diagnose this condition.

\section{Acknowledgment}

The authors thank Margaret A. McKinney for her work and artistic contribution for the illustration.

\section{Study funding}

No targeted funding reported.

\section{Disclosure}

J.R. Duvall reports no disclosures relevant to the manuscript. C.E. Robertson: honoraria from UpToDate as author; advisory board for Amgen, Alder, and Eli-Lilly. Go to Neurology. org/ $\mathrm{N}$ for full disclosures.

\section{Appendix Authors}

\begin{tabular}{llll}
\hline Name & Location & Role & Contribution \\
\hline $\begin{array}{l}\text { Jaclyn R. } \\
\text { Duvall, MD }\end{array}$ & $\begin{array}{l}\text { Mayo Clinic, } \\
\text { Rochester, } \\
\text { MN }\end{array}$ & Author & $\begin{array}{l}\text { Data collection and analysis, } \\
\text { drafting and revision of } \\
\text { manuscript }\end{array}$ \\
$\begin{array}{l}\text { Carrie E. } \\
\begin{array}{l}\text { Robertson, } \\
\text { MD }\end{array}\end{array}$ & $\begin{array}{l}\text { Mayo Clinic, } \\
\text { Rochester, } \\
\text { MN }\end{array}$ & Author & $\begin{array}{l}\text { Drafting and revision for } \\
\text { intellectual content }\end{array}$ \\
\hline
\end{tabular}

\section{References}

1. Headache Classification Committee of the International Headache Society. The International Classification of Headache Disorders, 3rd edition (beta version). Ceph alalgia 2013;33:629-808

2. Cruccu G, Finnerup NB, Jensen TS, et al. Trigeminal neuralgia: new classification and diagnostic grading for practice and research. Neurology 2016;87:220-228.

3. Di Stefano G, Maarbjerg S, Nurmikko T, Truini A, Cruccu G. Triggering trigeminal neuralgia. Cephalalgia 2018;38:1049-1056.

4. Maarbjerg S, Gozalov A, Olesen J, Bendtsen L. Trigeminal neuralgia: a prospective systematic study of clinical characteristics in 158 patients. Headache 2014;54 $1574-1582$. 
5. Maarbjerg S, Gozalov A, Olesen J, Bendtsen L. Concomitant persistent pain in classical trigeminal neuralgia: evidence for different subtypes. Headache 2014;54:1173-1183.

6. Abdeldaoui A, Oker N, Duet M, Cunin G, Tran Ba Huy P. First bite syndrome: a little known complication of upper cervical surgery. Eur Ann Otorhinolaryngol Head Neck Dis 2013;130:123-129.

7. Kawashima Y, Sumi T, Sugimoto T, Kishimoto S. First-bite syndrome: a review of 29 patients with parapharyngeal space tumor. Auris Nasus Larynx 2008;35:109-113.
8. Netterville JL, Jackson CG, Miller FR, Wanamaker JR, Glasscock ME. Vagal paraganglioma: a review of 46 patients treated during a 20 -year period. Arch Otolaryngol Head Neck Surg 1998;124:1133-1140.

9. Laccourreye O, Werner A, Garcia D, Malinvaud D, Tran Ba Huy P, Bonfils P. First bite syndrome. Eur Ann Otorhinolaryngol Head Neck Dis 2013;130:269-273.

10. Wong EH, Farrier JN, Cooper DG. First-bite syndrome complicating carotid endarterectomy: a case report and literature review. Vasc Endovascular Surg 2011;45:459-461.

\section{Disputes \& Debates: Rapid online correspondence}

The editors encourage comments on recent articles through Disputes \& Debates:

Access an article at Neurology.org/ $N$ and click on "COMMENT" beneath the article header. Responses will be posted within 3 business days.

Before submitting a comment to Disputes \& Debates, remember the following:

- Disputes \& Debates is restricted to comments about studies published in Neurology within the last eight weeks

- Read previously posted comments; redundant comments will not be posted

- Your submission must be 200 words or less and have a maximum of five references; reference one must be the article on which you are commenting

- You can include a maximum of five authors (including yourself)

\section{New AAN Practice Management Webinar Format Digs Deeper}

The new format offers a live, 30- to 45-minute webinar with expert faculty followed by several shorter recorded online lectures that explore the topic in greater depth. Each topic concludes with a 30-minute live webchat for further participant Q\&A. Purchase a single webinar series for \$99 or purchase a 2019 Practice Management Webinar subscription for only \$189-that's less than $\$ 32$ per webinar!

\section{Webinar Series}

- January 15 - Boss, MD: Managing a Better Practice

- March 12 - Understanding How You Get Paid

- May 21 - Everything You Wanted to Know About Your Patients but Were Afraid to Ask: Having Difficult Conversations with Patients from Vulnerable Populations

- August 13 - Increasing Revenue in Your Practice: Care Models, Ancillary Services, and Other Strategies

- October 1 - Using Technology for Better Practice Management of Stroke

- November 19 - Seeing the Future Clearly: How to Succeed in 2020

Learn more and register at AAN.com/view/webinar. 


\section{Neurology}

\section{Clinical Reasoning: A misdiagnosis of atypical trigeminal neuralgia}

Jaclyn R. Duvall and Carrie E. Robertson

Neurology 2019;93;124-131

DOI 10.1212/WNL.0000000000007790

\section{This information is current as of July 15, 2019}

\section{Updated Information \&} Services

\section{References}

Citations

Subspecialty Collections

Permissions \& Licensing

Reprints including high resolution figures, can be found at: http://n.neurology.org/content/93/3/124.full

This article cites 10 articles, 1 of which you can access for free at: http://n.neurology.org/content/93/3/124.full\#ref-list-1

This article has been cited by 1 HighWire-hosted articles: http://n.neurology.org/content/93/3/124.full\#\#otherarticles

This article, along with others on similar topics, appears in the following collection(s):

Trigeminal neuralgia

http://n.neurology.org/cgi/collection/trigeminal_neuralgia

Information about reproducing this article in parts (figures,tables) or in its entirety can be found online at:

http://www.neurology.org/about/about_the_journal\#permissions

Information about ordering reprints can be found online:

http://n.neurology.org/subscribers/advertise

Neurology ${ }^{\circledR}$ is the official journal of the American Academy of Neurology. Published continuously since 1951, it is now a weekly with 48 issues per year. Copyright @ 2019 American Academy of Neurology. All rights reserved. Print ISSN: 0028-3878. Online ISSN: 1526-632X.

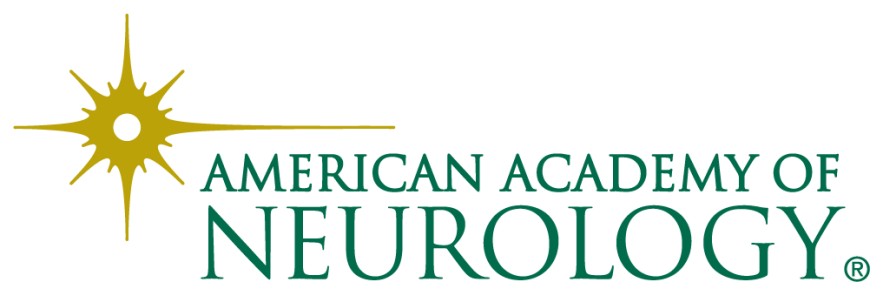

